\section{$\underset{\substack{\text { hommes } \\ \text { \& migrations }}}{ }$}

\section{Hommes \& migrations}

Revue française de référence sur les dynamiques

migratoires

$1327 \mid 2019$

Capitales européennes et diversité culturelle

\title{
Dora Djann, Ouverture à la française
}

Paris, éd. Emmanuelle Collas, 2019, 216 pages, $15 €$.

\section{Mustapha Harzoune}

\section{OpenEdition}

1 Journals

\section{Édition électronique}

URL : https://journals.openedition.org/hommesmigrations/10507

DOI : 10.4000/hommesmigrations. 10507

ISSN : 2262-3353

Éditeur

Musée national de l'histoire de l'immigration

\section{Édition imprimée}

Date de publication : 1 octobre 2019

Pagination : 200

ISBN : 978-2-919040-47-6

ISSN : 1142-852X

Référence électronique

Mustapha Harzoune, «Dora Djann, Ouverture à la française », Hommes \& migrations [En ligne], 1327 |

2019, mis en ligne le 01 octobre 2019, consulté le 08 janvier 2022. URL : http://

journals.openedition.org/hommesmigrations/10507; DOI : https://doi.org/10.4000/

hommesmigrations. 10507 


\section{Livres}

\section{Ouverture à la française}

Dora Djann, Paris, éd. Emmanuelle Collas, 2019, 216 pages, $15 €$.

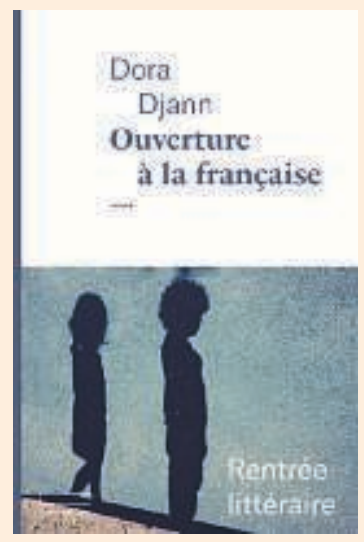

"Je viens souvent là, devant cette tour à Saint-Denis. Je reste dans la voiture et j'observe l'entrée de l'immeuble. J'ignore à quel étage il vit. On refuse de me dire où il habite pour que je ne puisse pas m'approcher plus près de lui.» Quelle entame! On se croirait dans un film, dans l'habitacle d'une voiture à guetter l'entrée d'un immeuble. Et on se demande: «Qui est cette femme? Qui attend-elle et pourquoi?» En deux phrases, Dora Djann, vient d'embarquer son lecteur dans ce premier roman écrit en très cours chapitres, ou plutôt fragments, parfois d'une page. La narratrice, Ziné, fille d'immigrés turcs, y consigne ses souvenirs. Finalement, on pense à un album photo. Un album de famille avec ses bonheurs et ses longueurs.

Dora Djann raconte une rupture entre une fille et son père. Bien sûr, on se doute du pourquoi de la chose: Ziné a décidé de s'émanciper. On ne plaisante pas avec ça, même dans une famille d'opposants tendance coco. Résultat, quinze ans de rupture et de silence. Rien de nouveau sous le soleil de l'immigration version turque (lire Sema Kiliçkaya). Entre cette première scène et la dernière, Dora
Djann scande les différentes étapes de cette histoire commencée à Gaziantep, à la frontière turcosyrienne, et qui se termine du côté de Saint-Denis. L'histoire d'un exil, en deux temps. D'abord le père, opposant politique de gauche, recherché par les autorités et cherchant à s'émanciper de l'autorité satrapique de son propre père. Pendant quatre ans, il vit sans papier dans la France de la liberté, celle de Rousseau et de Voltaire (croyait-il). Quatre ans sans donner de nouvelles, ou si peu, et sans pouvoir subvenir aux besoins de son épouse et de leurs trois enfants. Au bout de ces longues années, la mère décide de rejoindre son mari.

Dora Djann égrène les étapes: la ville, l'école, l'arrestation, la maison du grand-père, le départ, l'audition par les services de l'office français de protection des réfugiés et apatrides (Ofpra) et l'impossibilité de se faire enregistrer comme kurde et alévie - «pas turcs ni islam» répète le père -, le travail dans un atelier de couture, l'assassinat du grand-père au pays, etc. Il y a aussi le bonheur de se retrouver enfin réunis, fut-ce dans un petit studio du côté de Vaujours, entre tournois d'échecs, visites de l'opposition en exil et sardines grillées. Le père « regarde ses enfants s'agiter et devenir français» et, avec les années, il devient «un fantôme» au point que «le monde qui nous entoure nous évite autant que nous l'évitons».

Avec les premières règles arrivent les interdictions et les menaces. "On tue les filles qui perdent leur dé, quelle qu'en soit la raison» prévient sa mère! Et c'est parti: récit de mariage forcé, suicide d'une cousine et tentative de suicide de Ziné. Pour échapper à la pression familiale et communautaire, elle se réfugie dans le mariage mais avec un... Français. Déshonneur pour la famille et pour la lignée! "J'évite mon père, il m'évite aussi. » Jusqu'à la rencontre finale. Entre ces deux scènes, Ziné raconte son voyage à
Istanbul ou en terre kurde, à Diyarbakir, d'où elle revient transformée: "Désormais, une seule obsession: rejoindre la Résistance et devenir une Kurde des montagnes. » Cela tombe comme un cheveu dans la soupe ou comme Dieu sur Claudel, mais surtout, cela distingue Ziné de son père qui s'exila parce que lui, justement, était un pacifiste et refusait de porter les armes.

Pourtant, de son poste d'observation, Ziné redoute de cet homme un acte violent...

Mustapha Harzoune 